\title{
Laments and Serenades: Relationship Marketing and Legitimation Strategies for the Cultural Entrepreneur
}

\author{
Qualitative Market Research: An International Journal \\ Vol.7, No.3, pp.218-227, 2004.
}

By

Nicholas C. Wilson and David Stokes

Nicholas C. Wilson is Senior Lecturer in Small Business and Entrepreneurship at the Small Business Research Centre, Kingston Business School, Kingston University

n.wilson@kingston.ac.uk

David Stokes (PhD) is Assistant Director of the Small Business Research Centre, at Kingston Business School, Kingston University.

d.stokes@kingston.ac.uk

Tel: $+44(0) 2085472000$

Fax: +44 (0)208 5477140

Small Business Research Centre

Kingston University

Kingston Hill

Kingston upon Thames

Surrey KT2 7LB

Revised: October, 2003 
Keywords: relationship marketing; cultural entrepreneurship; legitimation; networks; finance;

\begin{abstract}
This paper investigates how the marketing/entrepreneurship interface functions within the cultural sector. Specifically, the paper considers how cultural entrepreneurs in the music industry market not to customers, but to networks that control the resources necessary to support entrepreneurial ventures. Evidence is drawn from the qualitative research of a study on access to finance by owner-managers of independent music companies ('cultural entrepreneurs'). The findings support the notion that 'legitimation' is a key factor in accessing such resources. Cultural entrepreneurs have difficulties in establishing either 'pragmatic legitimation' (derived from the self-interest of organisations across marketing networks) or 'cognitive legitimation' (derived from perceptions of normality and conformity within marketing networks). Marketing strategies at both individual and industry level are put forward to overcome these barriers. For individual businesses, a 'selection strategy' using creative clusters or a 'manipulation strategy' that manages the cultural environment are recommended. The implications for relationship marketing models are discussed.
\end{abstract}




\section{Introduction}

This paper investigates marketing and entrepreneurship in a very distinct context: marketing to financial markets by cultural entrepreneurs in the music industry. For a number of reasons, this context is particularly appropriate for examining the marketing / entrepreneurship interface. At a practical level, the ability to access financial capital is a core task of entrepreneurial behaviour and provides a very strict test of marketing capabilities. At a conceptual level, this perspective contributes to two contrasting but related trends at the marketing / entrepreneurship interface. The first is an increasing specialisation within each of the two disciplines. Researchers in marketing and entrepreneurship have focused their respective lenses on particular business environments with ever increasing magnifications in an attempt to make theoretical concepts more relevant to specific contexts. This has given impetus to the second trend: a theoretical convergence that reinforces the interface between the two disciplines.

\section{Marketing theory}

Within marketing theory there has been a shift away from the classical transactional approach to take into account the theoretical developments of market orientation, sectoral approaches, relationship marketing and networks (Christopher, Payne and Ballantyne, 1991; Gronroos, 1994; Deshpandé, 1999). Analysis of the marketing process has become increasingly specialised and sophisticated, as evidenced by the growth in special interest groups of the Academy of Marketing (AM, 2002). A particular aspect of this is the 
comparative discussion of marketing within large and small firms (Hulbert et al., 1998). Whilst some commentators (e.g. Nevin, 1995; Chaston, 2000a) describe a simple dichotomy between corporate and entrepreneurial marketing, Coviello, Brodie and Munro (1997) argue that SME marketing practice can be further distinguished into four types: Transaction, Database, Interaction and Network Marketing. In particular, interactive and network marketing rely on informality in developing markets and marketing communications (Stokes, 2000), thereby providing a direct bridge to the entrepreneurship literature. Marketing is 'an evolving philosophy' (Chaston, 2000a) and a key aspect of this evolution is the study of its relationship to management paradigms, including entrepreneurship.

\section{Entrepreneurship theory}

Although entrepreneurs are often typified as lone individuals thriving on independence, they also depend on co-operation and various forms of networks (Shaw, 1999). Early developments in entrepreneurship theory focused on the personality traits of individuals (Chell, Haworth and Brealey, 1991), but it is now widely accepted that entrepreneurial behaviour cannot be fully understood in isolation from the social and market networks within which entrepreneurs operate (Curran and Blackburn, 1994; Carson, Cromie, McGowan and Hill, 1995). At the same time as the development of generalised notions of entrepreneurship, the literature has expanded to include differentiated and specialised accounts using variables such as gender, family and ethnicity (Carter and Jones-Evans, 2000), market sector - such as technology-based firms (Oakey, 1994) and cultural 
entrepreneurship (Leadbeater and Oakley, 1999; Fillis and McAuley, 2000; Brindley, 2000; Ellmeier, 2003). In this paper, we follow Ellmeier's definition of 'cultural entrepreneurialism' - encompassing all-round artistic and commercial/business qualifications, long working-hours and fierce competition from bigger companies. It is in the disappearance of any separation between the artist/creator and non-creators/artists that this concept has begun to be used relatively widely. As such, the particular ability of the cultural entrepreneur to coordinate artistic and managerial resources (see Casson, 2003), can be seen as a defining characteristic of the use of the term 'entrepreneur'.

\section{Theoretical convergence - to a point}

This guest edition bears testament to the convergence taking place between the marketing and entrepreneurship literatures. Research at the marketing / entrepreneurship interface has gone further than a simple 'bolting together' of two distinct literatures. Indeed, some commentators now argue that marketing should be seen as a major domain within the entrepreneurship field, or vice versa, as they share a range of key concepts such as creativity, innovation, idea generation and opportunity identification within their respective areas (Hills and LaForge, 1992; Carson et al, 1995). However, an obvious danger in merging aspects of two rapidly developing theoretical disciplines is that researchers at the cutting edge of one compare their findings against a dated background of the other. As Coviello et al. (2000) suggest, it is now appropriate to assess entrepreneurial marketing practices in the context of a broader more contemporary 
perspective' (p.i) that takes into account the new paradigms of thought that have developed within existing marketing models, such as relationship and network marketing.

Aspects of relationship marketing do overlap with entrepreneurial concepts. A critical survival factor for a new venture is the development of a network of supportive relationships across the local business environment (Mumby-Croft, 1998; Aldrich, 1999). This strategy is supported by the literature on relationship marketing that has focused on an extended market (Hunt and Morgan, 1994; Christopher, 1995). In the years since the first 'Six Markets' model (Christopher, et al., 1991) brought more than the 'customer' market to the attention of researchers, relationship marketing has become increasingly sophisticated following general recognition that marketing encompasses networking to suppliers and other stakeholders (Peck, Payne, Christopher and Clark, 1999; Chaston, 2000b).

However, relationship marketing concepts tend to focus on established networks within the six markets and the need to develop long term relationships between them. Existing literature is less explicit on how to establish these networks and broker the relationships in the first place - the key task for an entrepreneur setting up a new venture. This is where the entrepreneurship literature can help. 


\section{Legitimation at the marketing / entrepreneurship interface}

Entrepreneurial network researchers have tended to focus on the role social resources play in founding new organisations. In particular, Hannan (1986) argues that a pattern of low rates of new firm foundation and high rates of closure exist where small firms in new business populations initially lack external 'legitimacy' - a social judgement of acceptance, appropriateness, and desirability. A key strategic issue affecting entrepreneurs attempting to establish and grow new ventures is their ability to attract such legitimacy — which in turn influences how that business can access new resources.

\section{Defining legitimation}

Suchman (1995: 574) describes legitimation as "a generalized perception or assumption that the actions of an entity are desirable, proper, or appropriate within some socially constructed system of norms, values, beliefs and definitions". Elsewhere, Ashforth \& Gibbs (1990) consider legitimacy as congruency between the values, norms and expectations of society and the activities and outcomes of the organisation. Zimmerman and Zeitz (2002) regard legitimacy as a relationship [original emphasis] between the practices and utterances of the organization and those that are contained within, approved of, and enforced by the social system in which the organisation exists. They go on to define 'social system' here as an interacting collectivity that has ongoing patterns of scripts, rules, norms, values and models (p.416). 
Barron (1998), following Suchman (1995), distinguishes between three forms of legitimacy:

- Pragmatic legitimacy 'rests on the self-interested calculations of an organization's most immediate audiences' (Suchman, 1995: 578). To that extent, potential customers and suppliers (or finance providers in the case of this paper) must believe that involvement will be in their interests. Such self-interested calculation, or 'framing' is a key dimension of any 'market' (Callon, 1998).

- Moral legitimacy 'reflects a positive normative evaluation of the organization and its activities' (Suchman, 1995:579). This is probably the definition closest to its meaning in common usage.

- Cognitive legitimacy, describes where the organization is 'taken for granted' as being the natural way of achieving something. Aldrich (1999) goes on to describe cognitive legitimacy from a producer's point of view as meaning that new entrants to an industry are likely to copy an existing organizational form, rather than experiment with a new one. In addition to cognitive legitimacy, Zimmerman and Zeitz (2002) suggest that new ventures can derive legitimacy from their industry, adding to the legitimacy they have from other sources.

In this paper we restrict our focus to pragmatic and cognitive legitimacy. Industry legitimacy is difficult to discern from either pragmatic or cognitive legitimacy in practice, so this is not identified separately. We exclude moral (or sociopolitical) legitimacy on the grounds that moral and regulatory acceptance are generalised constraints of new 
venture activity. Figure 1 outlines the conceptual logic that underpins this paper's contribution to the marketing / entrepreneurship interface.

\section{Take in Figure 1}

In line with the first trend at the marketing / entrepreneurship interface (increasing specialisation), the context for researching legitimation is specific both in terms of marketing (to finance markets) and entrepreneurship (by 'cultural entrepreneurs' in the music industry).

\section{Supply and demand in financial markets for the music industry}

The music industry is one of Britain's biggest and most culturally significant industries. For over four decades, Britain's music companies have been world leaders. The industry's growth has been rapid, generating over 130,000 jobs and contributing $£ 3.2$ billion to the value of the UK economy (National Music Council, 1999). Over 90\% of music businesses in the UK are small or medium-sized enterprises and these are widely seen to be the source of much of the creative potential for the industry as a whole. However, anecdotal evidence has suggested that these businesses face particular difficulties in accessing finance.

A number of specific supply-side and demand-side difficulties have been identified that create barriers to successful marketing to obtain finance. These include complex chains 
of royalties and fees, which lengthy contracts make more difficult for potential funders to understand (Passman, 1995); the intangible nature of the assets held by many music businesses (copyrights and royalties) which can be difficult to value; and perceptions of the high risk nature of the industry - increased by dependence on the vagaries of fashion and individual artists.

Some have argued that underlying these marketing difficulties for creative industries are the specific characteristics of creative products and services themselves. For example, creative products display 'quality uncertainty' (Caves, 2000; Kretschmer, Klimis and Choi, 1999) whereby it is difficult to assess how 'good' a product is before, during and even after delivery. Anecdotal evidence points to relationships for the provision of finance emerging between the many smaller music businesses and their larger counterparts (either the few medium-sized producers and distributors, or the 'majors' Sony; BMG: EMI; Polygram; Warner Music). Even where differences exist between the smaller 'independents' and the majors, it could be that their bond (through cognitive legitimation) is in fact stronger than that between music businesses and formal finance providers. Legitimacy may motivate such investors by signalling the organisation's commitment to the proper scripts, rules, norms, values and models (Zimmerman and Zeitz, 2002). At a general level, recalling Hannan (1986), there is every reason to think that legitimacy will play a key role in determining the success rates of new ventures, and their ability to access finance. However, this is unlikely to be confined to an issue of new venture creation alone. More established cultural firms also encounter issues of legitimation, as is outlined below. 


\section{Legitimation, Network Governance and the Cultural Entrepreneur}

O'Connor's research for the ICISS Project at the Manchester Institute for Popular Culture has pointed to the importance of increasing the visibility and recognition of the many small companies and enterprises in the cultural sector, which is essentially dominated by big media companies (O'Connor, 2000). This research has also pointed to the potential dilemma faced by established small enterprises in the cultural sector whereby they are categorised as commercial by government cultural support but regarded by business as being 'non-professional'. A deficit of legitimacy appears to play a part in propagating the widely held perception that creative and cultural sector firms are intrinsically high risk. Such a blanket approach to risk may unnecessarily count against some cultural entrepreneurs.

Taking into account the complex nature of exchanges in conditions of demand uncertainty (Peterson and Berger, 1971), some commentators have suggested that relationships between parties in the creative industries are subject to a particular type of interfirm coordination, or 'network governance' (Jones, Hesterly and Borgatti, 1997). Such coordination relies on strongly embedded network ties (Granovetter, 1992) and emphasises shared norms, values and beliefs. On this basis, cognitive legitimation also plays a vital role in influencing how things get done. We propose a basic model (Figure

2) that illustrates the different legitimation types to be expected within and across the 
networks involved in attempts by cultural entrepreneurs in the music industry to market themselves to finance providers.

\section{Take in Figure 2}

Two further propositions put forward by Zimmerman and Zeitz (2002) are also central to this paper's enquiry. Firstly, legitimacy improves the chances of acquiring all the various resources needed to survive and grow, including financial, social and human capital (Aldrich \& Fiol, 1994; Harman \& Freeman, 1989). Thus, the likelihood of an entrepreneur marketing successfully to key suppliers depends on the level of their venture's legitimacy. This is considered in relation to the ability of the cultural entrepreneur to access finance. Secondly, an entrepreneur can take specific marketing actions to improve their legitimacy rating in a deliberate, goal-oriented strategy. Four specific legitimation strategies have been put forward: conforming to, selecting, manipulating, and/or creating the environment in which it exists (Zimmerman and Zeitz, 2002). The application of such strategies in the context of the cultural entrepreneurs' marketing to the finance sector will be considered in light of the research findings.

\section{METHODOLOGY}

The empirical results of this paper are from a study commissioned by the Department for Culture, Media and Sport which had the overall aims of examining how SMEs in the music industry access finance to fund their growth, and the key reasons for any problems encountered. Parts of the study required measurement of specific variables (e.g. the range 
of finance options actually being used), and hence indicated a quantitative research method. Other aims required investigation of attitudes and perceptions (e.g. the problems in accessing finance and key reasons for this) that indicated a qualitative research process. A multi-method research design was therefore used to meet the research aims: in-depth interviews with cultural entrepreneurs (10), industry representatives (10), professional advisors (4), finance providers (4); a telephone survey of 310 music businesses; a postal questionnaire to 410 banks, and seven illustrative case studies of music companies. Mixed method designs are particularly useful for researching contextual issues with multiple aims, as can be the case in research at the marketing/entrepreneurship interface (Gilmore and Coviello, 1999). However, the focus of this paper is on the perceptions and roles of both cultural entrepreneurs and potential financial providers operating within complex networks. Such an evaluation requires the richness and depth of data available through qualitative research techniques, as recommended by previous researchers into the marketing networks of entrepreneurs (e.g. Hill, McGowan and Drummond, 1999). Most of the data drawn on for this paper is therefore from the interviews and case studies.

The sampling groups for interviews included representatives of the main trade associations (e.g. the British Phonographic Institute and the Association of Independent Musicians), as well as individual owner-managers from each of the six music sectors under review: record companies, music publishers, artist managers, promoters, recording services and online music companies. Representatives of high street banks, specialist banks, venture capitalists, and other professional service providers (music industry 
accountants and lawyers) were also included. Semi-structured interview plans were prepared prior to the interviews themselves, allowing for a degree of informality within a consistent framework. The researchers attempted to minimise response bias through seeking the trust of the respondents in an informal atmosphere.

The qualitative data, on which most of this paper is based, was analysed using general analytical procedures (Miles and Huberman, 1994), involving the systematic disaggregation and re-aggregation of written records into themes or categories of data through coding (Curran and Blackburn, 2001). The results are presented according to these key themes, with clear labeling of all quotes indicating which respondent's views are being expressed (see Scase and Goffee, 1982).

\section{RESULTS}

\section{Pragmatic Legitimation between market networks}

\section{Barriers to market entry}

Difficulties between the music and finance networks manifested themselves most deeply during the start up phase. The structural and risk norms of financiers were most at variance with the needs of cultural entrepreneurs when they were setting up a new venture that had little to legitimise a claim for financial support. The need for track record, for some means of reassuring potential investors or lenders appears paramount: 
It is a 'chicken and egg' situation - you can't get the catalogue without developing careers, but you can't finance unknown bands...

cultural entrepreneur (record company 1)

\section{The 'Culture Gap' between networks}

One of the most widely referred to difficulties experienced by representatives of both networks was the problem of being 'understood':

It is a dialogue problem - the music industry and banks don't speak the same language

Industry representative 1

It's a cultural problem...there is no obvious link between people creating business and financiers

cultural entrepreneur (record company 2)

Whilst it is generally acknowledged that there is not always a 'harmony of interests' between owner-managers / investors / or sponsors (DCMS 2000, p.13), the situation for music businesses appears to be exacerbated by the focus on the differences between the two groups, as opposed to the areas of mutual agreement. In fact, the reported lack of understanding was less of a two-way phenomenon but principally expressed as the finance providers not 'understanding' the music industry. 
Over and above generalised perceptions, there was an important distinction made between the views of finance-providers in general, and those of individuals working in that field. One online music business owner observed:

Venture capitalists are 'herd-like' - there aren't too many contraries. However, our 'champions' in the finance industry are the younger members of the VC team - people who actually appreciate the connections and importance of music

cultural entrepreneur (online music 1)

This highlights the potential importance of individual dyadic relationships in influencing or developing legitimation across the music and finance providing market networks (see Halinen, Salmi, and Havila, 1999).

\section{Image of the Music Industry}

Many music businesses are regarded by finance providers as 'lifestyle' businesses. One of the record companies commented, "being in the music industry is not perceived as being 'serious' until you are successful at it". To this extent, legitimacy is dependent on evidence of success rather than the 'potential' for success. Another example of such 'evidence' is the return on investment delivered by music business entrepreneurs in the 
past. The research raised the concern that the industry provides few examples of businesses that have provided large returns for investors:

Partly it is the image or character of the industry. There is no great history of investment. There are not many rags to riches stories of start-ups becoming big public companies and making lots of money for investors.

cultual entrepreneur (record company 1)

There is agreement from both the music industry and finance-providers that marketing and financial skills of music entrepreneurs overall have historically not been of a high standard:

It is very much viewed as a 'cottage industry', with esoteric rights being marketed by people who have no clearly demonstrable financial skills.

finance provider 1

There have been few attempts by music industry associations to promote a better image of how music entrepreneurs manage their businesses, despite the fact that this would appear to be a suitable strategy for developing pragmatic legitimation across networks. 
The importance between striking the right marketing balance between enthusiastic promotion and over-eager selling was an issue raised by a number of respondents:

There is also a perception of people in the music industry that because they are always seen to be selling / promoting, pushing their bands, they are automatically selling, pushing and promoting their business... and that all the information you get in terms of prospects is going to be inflated...because everyone's got the next "great artist"!

professional advisor 1

\section{Market position of the music industry as 'high risk'}

The level of uncertainty within the music business is compounded by short termism (the powerful influence of changing fashions and tastes in music), the threat of piracy (as digital distribution becomes more prevalent), and the difficulty of monitoring and patrolling territory agreements in the new Internet age. All of these perceptions about the music industry lead to a strongly endorsed view of it being a 'high risk' industry. As one respondent observed:

The music industry automatically generates a high score...security (tangible security rather than intangible) has to be that much better for the overall proposition to fit underneath the generic High St bank's criteria $\ldots$

professional advisor 2 
Given the core values of banks and venture capitalists that insist on sophisticated assessment of 'risk', it is understandable that broad-brush perceptions about the high risk nature of the industry will deprive music businesses of pragmatic legitimacy.

\section{Cognitive legitimation within market networks}

\section{Music industry network - the comfort factor and self-image}

Within the music industry a number of factors legitimate the marketing approach adopted by cultural entrepreneurs in their attempts to access financial markets. These lead to both negative and positive attitudes to raising finance within the industry.

The cultural entrepreneur's decision as to what kind of financial market to target for their particular music business appears to be strongly dependent on what might be termed the 'comfort factor'. Such comfort is closely related to the 'taken for granted' nature of cognitive legitimation. Several interviewees used the word 'comfort' in the context of being 'at ease' with a particular finance source, as opposed to reaching a decision on the basis of a more rigorous analysis of the suitability of the various types of financial products on offer. Interestingly, despite an 'us and them' culture between smaller businesses and the 'majors', there remains a strong bond (emotionally and financially) between smaller and larger music businesses. One record company cultural entrepreneur, who was offered bank finance, explained why she turned this down in favour of a larger record company (see note to Figure 2): 
I went to a larger record company because I knew they would be more understanding of the dilemmas of my business and the uncertainty of the business plan. I also knew they could give me access to foreign markets, because they had established foreign territories.

cultural entrepreneur (record company 3 )

This is indicative of a strong flow of investment that circulates within the music industry. Rather than looking to external markets such as banking and venture capital, many music businesses seek funding from internal markets within the industry. This income flow manifests itself at a variety of levels, including offering studio space in exchange for a share of profits from an album, through to a major record company or distributor taking an equity stake in a smaller label (corporate venturing).

The self-image widely held within the music industry is that of being 'different' from other industries. This stems largely from the vocational aspect of an industry that deals with an intangible and difficult to value product. It is likely, however, that in an industry where 'difference' is 'taken for granted', the role of cognitive legitimation will be particularly strong. A music publisher put it this way:

I always think it a great mistake to think of music as being just like any other product. There's a difference of kind not degree. To think 
that you can look at the record industry in the same way as you can

a baker or a service industry - it really misses the point!

cultural entrepreneur (publisher 1)

\section{The Finance Provision Network}

While the views reported above are focused on cognitive legitimation within the music industry, the norms, values and beliefs of the finance providing network are also central to how market relationships are built up over time. A strong example of where a music business has benefited from its closer association with these norms, values and beliefs was an online music business, whose management team was assembled from City and management consultancy backgrounds. The director explained how easy it had been for his management team to access the venture capital required, precisely because they did speak the same language as the venture capitalists:

Raising finance was extremely easy for us because we caught a wave, it is an exciting sector, and more than anything, the management team spoke the language of the investors. Very often in the music industry the management team doesn't have the language at all!

cultural entrepreneur (online music 1) 
Of course, whether or not cultural entrepreneurs could (or should) learn to conform to the expectations of finance providers concerning creative industries remains a debatable question. This is taken up further in the discussion below.

\section{Discussion}

The qualitative findings of this research are strongly supportive of the importance of legitimation as a factor in determining whether cultural entrepreneurs can successfully market their business to access necessary resources such as finance. To that extent Zimmerman and Zeitz's (2002) proposition that the greater the level of a new venture's legitimacy, the more resources it can access, appears well founded. In terms of pragmatic legitimation across networks it was clear that this could only be achieved through the social construction of norms, values, beliefs and definitions within a common 'language'. Without this, unhelpful perceptions of the music industry by finance providers will be difficult to overcome. In the particular context of cultural entrepreneurship, cognitive legitimation within networks also appeared to have an important role to play. While small music businesses continue to feel more 'comfortable' by developing relationships (either formal or informal) with larger music businesses rather than with banks or venture capitalists, the take-up of external financial resources will be limited.

The potential for cultural entrepreneurs in the music industry to develop legitimacy and, in turn, marketing relationships with finance providers is highlighted in this study. The quantitative research undertaken in parallel with the findings reported in this article found that three-quarters of small music businesses (77.6\%) considered the issue of access to 
finance acting as a barrier to growth for the industry to be either 'significant' or 'very significant'. There is certainly room for improvement in existing marketing relationships, therefore.

This raises the issue of what can be done to align the levels of pragmatic legitimation across networks and cognitive legitimation within networks and so reduce the finance barrier for cultural entrepreneurs in the music industry. A key proposition put forward in the literature review was that a new venture can take marketing actions to increase visible consistency with the environment by applying one or a number of "legitimation strategies' (Zimmerman and Zeitz, 2002, p.423). Specifically, these included the four strategies of conformance, selection, manipulation, and creation.

For the majority of new ventures in the music industry, conformance or 'following the rules' represents the path of least resistance. However, overall this approach appeared to raise barriers to successful marketing (i.e. difficulties with finance provision). This might result from particularly clear industry norms and beliefs (cognitive legitimacy) reducing the ability of the cultural entrepreneur to 'play the game' by the finance providers 'rules' (pragmatic legitimacy). There is clearly a case for suggesting that a more 'knowing' strategy of conformance would be beneficial to cultural entrepreneurs. There was no evidence of any music business adopting the most innovative approach (the 'creation' strategy), presumably because the creation of the social context is only appropriate for completely new industries. 
The remaining two strategies, selection and manipulation represent differing degrees of deliberate goal-oriented behaviour. A selection strategy involves locating in a favourable environment (Suchman, 1995). From the qualitative interviews carried out in this research there was little evidence of explicit selection strategies being undertaken by cultural entrepreneurs in the music industry. However, music businesses are known to locate within 'creative clusters' (geographic concentrations of interconnected companies), in London, the South East, Manchester, Sheffield, and Merseyside, for example. The Clusters Group at the UK's Department of Trade and Industry notes that 'dividends from creative clusters can be enormous in terms of civic image, training and engagement in the economy as well as purely economic terms' (Creative Clusters conference, 2002). We would argue that such dividends would appear to result, at least in part, from the related increased cognitive and pragmatic legitimation such geographic closeness brings.

Perhaps the most appropriate legitimation strategy available to cultural entrepreneurs is the manipulation strategy, which involves a more innovative approach. The innovator "must often intervene pre-emptively in the cultural environment in order to develop bases of support specifically tailored to the distinctive needs" of the organisation (Suchman, 1995: 591). The notion of pre-emptive intervention suggests a deliberate approach to strategy that sits uncomfortably alongside the opportunistic behaviour of entrepreneurial individuals. On the other hand, to the extent that the entrepreneur is an innovator in the Schumpeterian sense, this manipulation strategy would seem appropriate for cultural entrepreneurs to adopt. The findings reported in this article suggest that a rather limited set of cultural entrepreneurs have benefited from such a strategy. The example of the online music business that had no difficulties in accessing venture capital serves to 
demonstrate this. Strategic intervention at the industry level then is also required to overcome legitimation problems. This might include developing and promoting training seminars at targeted banks at a regional level; forming industry-specific Business Angel Networks; or identifying role models that can be publicised as examples of best practice.

\section{Implications for entrepreneurial relationship marketing models}

This research at the marketing / entrepreneurship interface has clear implications for the development of relationship marketing theory, including the Six markets model:

Firstly, existing relationship marketing models tend to assume that market building has already taken place. Issues of legitimation have themselves been 'taken for granted' to some extent. While this is of particular concern in the context of new venture creation, it has also been shown to be important in creative industries, where short-term or fashion driven products and services are innovated regularly.

Secondly, relationship marketing models do not easily account for stakeholders being members of more than one market domain. In this study there was evidence of some music businesses effectively occupying at least five of the six market 'domains' put forward in the six market model. While it is convenient to label enterprises according to such criteria as record producer or music publisher, the reality of the creative production chain in this industry involves often complex interactions and market relationships. Such relationships are subject to change in the level of legitimacy over time. 
Thirdly, relationship marketing models are based at the organisational level, and do not readily account for the nature of change across networks and industries (or the role of entrepreneurial individuals within that change process). Where cultural entrepreneurs adopt a manipulation legitimation strategy there will be the potential for changes to be affected across both dyadic relationships (with individual finance providers) and the network as a whole (see Halinen et al, 1999). Broadly speaking, unless legitimation is taken into account there will be a danger that relationship marketing models provide only a partial picture of where the marketing focus for cultural entrepreneurs is most required.

\section{References:}

Academy of Marketing, (2002), Proceedings of the Academy of Marketing Conference, July, Nottingham University.

Aldrich, H. E. (1999), Organizations Evolving, Sage, London.

Aldrich, H.E. and Fiol, C.M. (1994) "Fools rush in? The institutional context of industry creation", Academy of Management Review, Vol 19 pp.645-670

Ashforth, B.E. and Gibbs, B.W. (1990) "The double-edge of organizational legitimization”, Organization Science, Vol 1 pp.177-194

Barron, D.N. (1998) "Pathways to Legitimacy Among Consumer Loan Providers in New York City, 1914-1934”, Organization Studies, Vol 19 No 2 pp.207-233

Brindley, P. (2000), New Musical Entrepreneurs, IPPR, London. 
Callon, M (1998), The Laws of the Markets, Blackwell Publishers/The Sociological Review, Oxford.

Carson, D., Cromie, S., McGowan, P. and Hill, J. (1995), Marketing and Entrepreneurship in SMEs: an Innovative Approach, Prentice Hall, London.

Carter, S. and Dylan-Jones, D. (2000), Enterprise and Small Business: Principles, Practice and Policy, FT Prentice Hall, London.

Casson, M. (2003) The Entrepreneur: An Economic Theory, Edward Elgar, Cheltenham

Caves, R. (2000), Creative Industries: Contracts between Art and Commerce, Harvard University Press, Cambridge, Mass.

Chaston, I. (2000a), Entrepreneurial Marketing, MacMillan Press, Basingstoke.

Chaston, I. (2000b) "Organisational Competence: Does Networking Confer Advantage for High Growth Entrepreneurial Firms", Journal of Research in Marketing and Entrepreneurship, Vol. 2, Issue 1, Spring, 36-56

Chell, E., Haworth, J., and Brealey, S. (1991), The Entrepreneurial Personality: Concepts, Cases and Categories, Routledge, London.

Christopher, M., Payne, A. and Ballantyne, D. (1991), Relationship Marketing, Butterworth-Heinemann, Oxford.

Christopher, M. (1995) "Networks and logistics: Managing supply chain relationships", paper presented to the third international colloquium in Relationship Marketing, Monash University, Melbourne

Coviello, N.E., Brodie, R.J. and Munro, H.J. (2000) "An investigation of marketing practice by firm size", Journal of Business Venturing, Vol 15 pp.523-545 
Coviello, N.E., Brodie, R.J., and Munro, H.J. (1997) "Understanding contemporary marketing: Development of a classification scheme", Journal of Marketing Management, Vol 13 No 6 pp.501-522

Creative Clusters (2002), Summit Conference, 20-23 November, Sheffield, www.creativeclusters.co.uk.

Curran, J. and Blackburn, R. (2001) Researching the Small Enterprise, Sage, London

Curran, J. and Blackburn, R. (1994), Small firms and Local Economic Networks, Paul Chapman Publishing, London.

DCMS (2000), Connecting Creativity with Capital: Finance Conference, Creative Industries Taskforce, DCMS.

Deshpandé, R. (1999), Developing A Market Orientation, Sage, London.

Doyle, P. (1995) "Marketing in the new millennium", European Journal of Marketing, Vol 29 No.13, 23-41

Ellmeier, Andrea (2003) 'Cultural Entrepreneurialism: On the Changing Relationship Between the Arts, Culture and Employment', in The International Journal of Cultural Policy, 9 (1), pp.3-16

Fillis, I. And McAuley, A. (2000) "Modelling and Measuring Creativity at the Interface", Journal of Marketing Theory and Practice, Vol.8, No. 2, pp. 8-17

Gill, J. and Johnson, P. (1997) Research Methods for Managers, Paul Chapman, second edition, London

Gilmore, G. and Coviello, N. (1999) "Methodologies for Research at the Marketing/Entrepreneurship Interface", Journal of Research in Marketing and Entrepreneurship, Vol.1 No. 1 Fall, pp. 41-53 
Granovetter, M. (1992), Problems of explanation in economic sociology, in N.Nitin \& R.Eccles (Eds), Networks and organizations: Structure, form, and action, pp.25-56, Harvard Business School Press, Boston.

Gronroos, C (1990) "Relationship Approach to marketing in services contexts: The marketing and organisational behaviour interface”, Journal of Business Research, Vol 20, pp.3-11

Gronroos, C. (1994) "From marketing mix to relationship marketing: Towards a paradigm shift in marketing", Asia-Australia Marketing Journal, Vol 2 No 1, pp.929

Gummesson, E. (1996) “Towards a theoretical framework of relationship marketing”, in Proceedings of the International Conference on Relationship Marketing, Berlin, pp.5-18

Halinen, A., Salmi, A. \& Havila, V. (1999) "From Dyadic Change to Changing Business Networks: an Analytical Framework", Journal of Management Studies, Vol 36 No 6, November

Hammersley, M. (1990) Reading Ethnographic Research: A Critical Guide, Longman, London

Hannan, M.T. (1986) "Competitive and Institutional Processses in Organizational Ecology” Technical Report 86-13, Department of Sociology, Cornell University Hansen, E.L. (1995) "Entrepreneurial Networks and New Organization Growth", Entrepreneurship Theory and Practice, Summer

Harman, M.T. and Freeman, J. (1989), Organizational ecology, Harvard University Press, Boston. 
Hayek, F. (1945) "The Use of Knowledge in Society”, American Economic Review, 35, pp.519-530

Hill, J. McGowan, P. and Drummond, P. (1999) “The Development and Application of a Qualitative Approach to Researching the Marketing Networks of Small Firm Entrepreneurs”, Qualitative Market Research: An International Journal, Vol.2, No. 2, pp 71-78

Hills, G.E. and LaForge, R.W. (1992), Marketing and entrepreneurship: The state of the art, in D.L. Sexton and J.D. Kasarda (eds) The State of the Art of Entrepreneurship, Babson College, Wellesley.

Hulbert, B., Day, J. and Shaw, E. (1998), Proceedings of the Academy of Marketing and UIC/MEIG-AMA Symposia on the Marketing and Entrepreneurship Interface, Nene University College, Northampton.

Hunt, S.D. and Morgan, R.M. (1994) "Relationship marketing in the era of network competition”, Marketing Management, Vol 3 No.1, pp.18-28

Jones, C., Hesterly, W.S. and Borgatti, S. (1997) A General Theory of Network Governance: Exchange Conditions and Social Mechanisms. Academy of Management Review Vol 22, pp.911-945

Kretschmer, M., Klimis, M., and Choi, C.J. (1999) "Increasing Returns and Social Contagion in Cultural Industries”, British Journal of Management, Vol 10 pp.S61S72

Leadbeater, C. and Oakley, K. (1999), The Independents: Britain's new cultural entrepreneurs, Demos, London.

Miles, M.B. and Huberman, A.M. (1994) Qualitative Data Analysis, Sage, London 
Mumby-Croft, R. (1998), Strategic Marketing for SMEs - its Role in Sustaining Small Company Viability, in Hulbert, Day and Shaw, E. (eds.) Proceedings of the Academy of Marketing and UIC/MEIG-AMA Symposia on the Marketing and Entrepreneurship Interface, pp. 131-136, Nene University College, Northampton.

National Music Council (1999), A Sound Performance: The Economic Value of Music to the United Kingdom, NMC, London.

Nevin, J.R. (1995) "Relationship marketing and distribution channels: Exploring fundamental issues", Journal of the Academy of Marketing Science Vol 23 No 4 pp.327-334

Oakey, R. (1994), New Technology-Based Firms in the 1990s, Paul Chapman, London.

Passman, D.S. (1995), All You Need to Know About the Music Business, Penguin Books, London.

Peck, H., Payne, A., Christopher, M. and Clark, M. (1999), Relationship Marketing Strategy and Implementation, Butterworth-Heinemann, Oxford.

Peterson, R.A. and Berger, D.G. (1971) "Entrepreneurship in Organizations: Evidence from the Popular Music Industry", Administrative Science Quarterly, Vol 16 No 1, pp. $97-108$

Porter, M. E. (1990), The competitive advantage of nations, Free Press, New York.

Scase, R. and Goffee, R. (1982) The Entrepreneurial Middle Class, Croom Helm, London

Shaw, E. (1999) "Networks and their Relevance to the Entrepreneurial/Marketing Interface: a Review of the Evidence", Journal of Research in Marketing and Entrepreneurship, Vol.1 No. 1 Fall, pp 24-40 
Stokes, D. (2000), Marketing and the Small Firm in Carter, S. and Jones-Evans, D. (eds.), Enterprise and Small Business, Pearson Education, Harlow.

Suchmann, M.C. (1995) “Managing Legitimacy: Strategic and Institutional Approaches”, Academy of Management Review, Vol 20 No 3 (July), pp.571-610

Zimmerman, M.A. and Zeitz, G.J. (2002) "Beyond Survival: Achieving new venture growth by building legitimacy", Academy of Management Review, Vol 27 No 3, pp.414-431

\section{Figure 1}

\section{Network legitimation and the interface: conceptual overview}

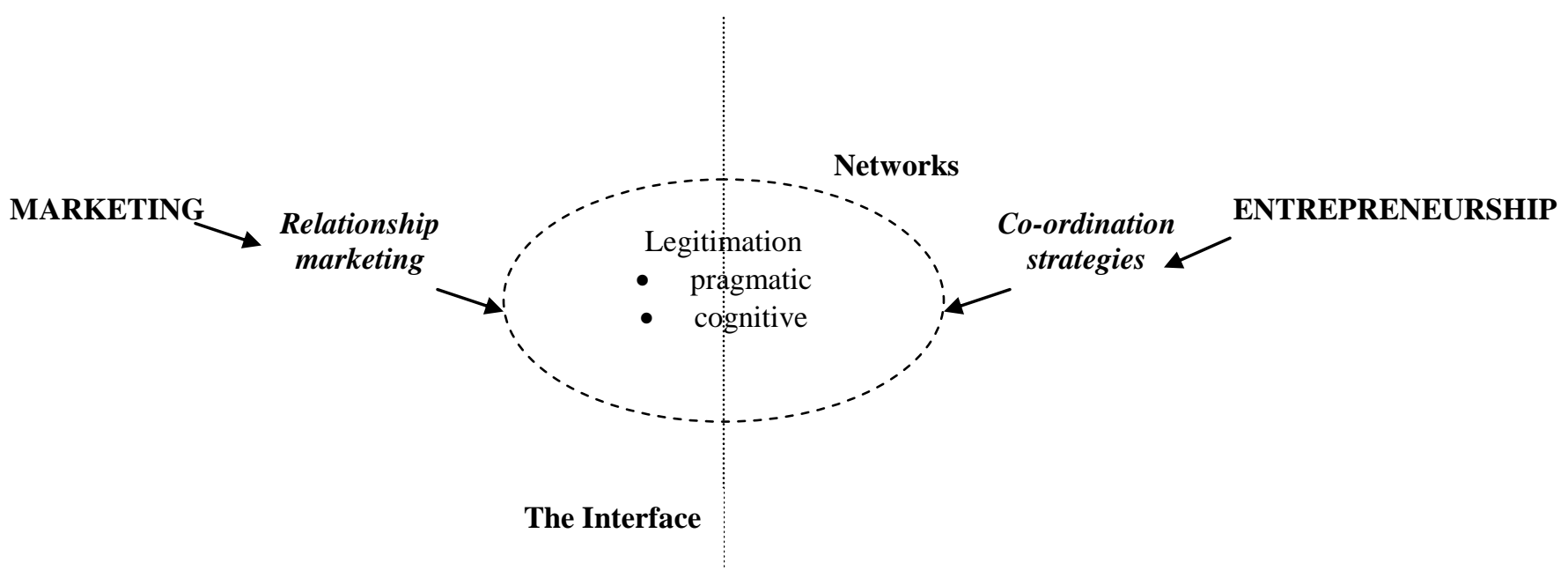


Figure 2

\section{Legitimacy Within and Across Cultural Market Networks}

Music Market Network

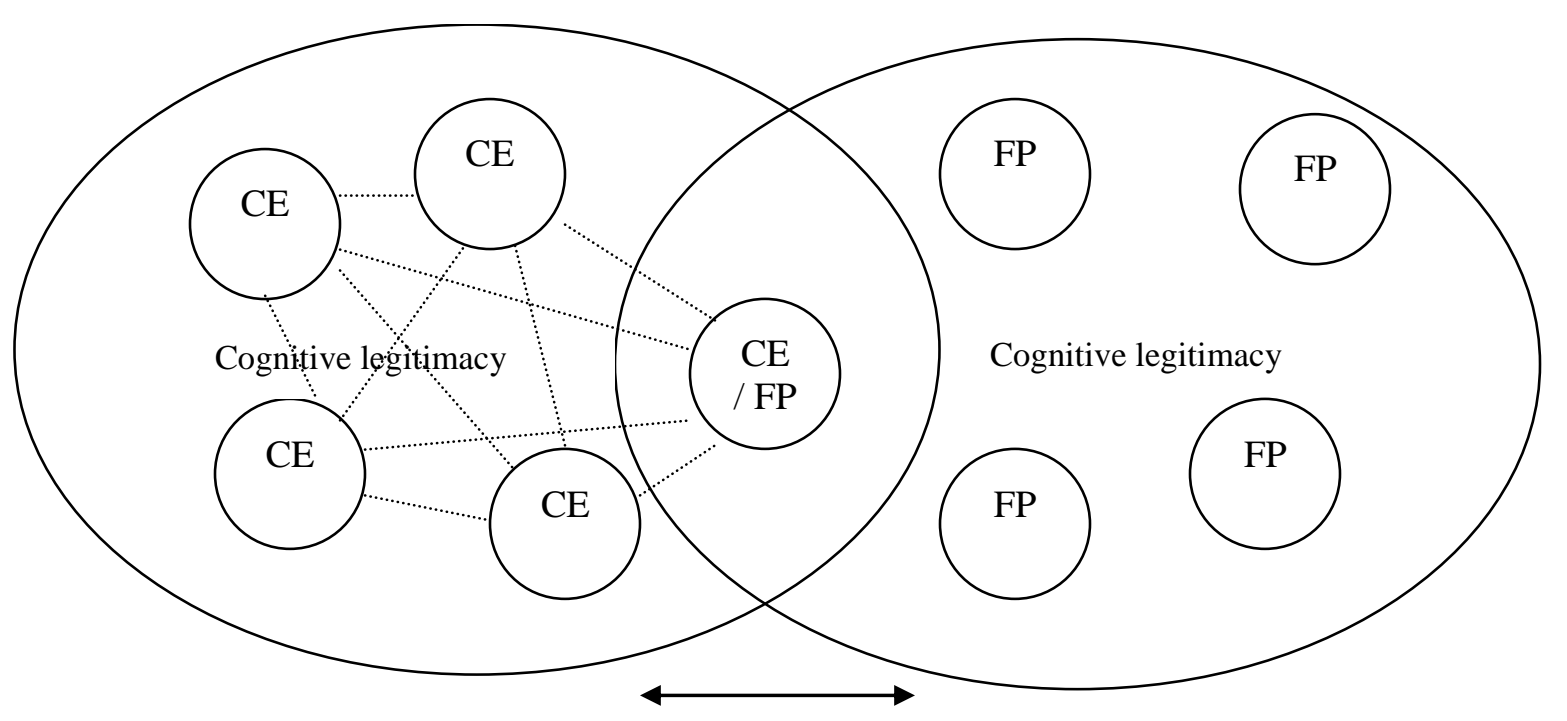

Pragmatic legitimacy

Finance Providers Market Network

$\mathrm{CE}=$ cultural entrepreneur

$\mathrm{FP}=$ finance provider

$\mathrm{CE} / \mathrm{FP}=$ evidence reported here suggests some cultural entrepreneurs are also finance providers

Network governance 